Apidologie, 1976, 7 (2), 109-111.

\title{
GALACTOSE, A SUGAR TOXIC TO HONEY BEES, FOUND IN EXUDATE OF TULIP FLOWERS
}

\author{
Roy J. BARKER and Yolanda LEHNER \\ U. S. Dept. of Agriculture, Agric. Res. Service, \\ 2000 E. Allen Road, Tucson, AZ 85719
}

\section{SUMMARY}

Thin-layer chromatography on silicic acid revealed galactose, some fructose and traces of raffinose (or melibiose) in stigmatal exudate.

Key words : galactose; Apis mellifica L; toxicité; nectar; Tulipa.

When dead honey bees, Apis mellifera L., were found in flowers of white scented Darwin tulips, Geissler and Steche (1962) suspected poisoning by toxic sugars. When they subjected extracts from thoraces of the dead bees to Orcin reaction, they obtained an absorption spectrum matching that of mannose. (Galactose had a similar absorption spectrum.) Because both sugars are toxic to honey bees (confirmed by BARKER and LEHNER, 1974), the report left a strong impression that tulips had poisoned the bees. Although Geissler and STEChe recognized the possibility that galactose or mannose could have been produced " post mortem ", no data on analysis of tulips were given.

We have analyzed stigmatal exudate of tulips and found galactose.

\section{MATERIALS AND METHODS}

Blooms of Jewels of Spring tulips (Tulipa greigii Regel) were covered with paper bags overnight. At 0800 on April 4, exudate from the 3 grooves on the tip of the stigma was collected in 1 or $10 \mu l$ capillary tubes and stored at $-10^{\circ}$. In 3 days, 6 samples and standard mixtures of 12 sugars were spotted onto thin-layer plates coated with silica gel and chromatographed by a two-dimensional method (BARKER and LEHNER, 1974). 


\title{
RESULTS
}

The developed chromatograms (fig. 1) showed surprisingly low levels of sugars ( $<5 \%$ vs. the $30 \%$ usually found in nectars). The chromatograms required 0,1 to $1,5 \mu \mathrm{l}$ of exudate to give detectable spots of sugar. Comparison with standards run concurrently gave crude estimates of $12 \mu \mathrm{g} / \mu \mathrm{l}$ for galactose $(1,2 \%), 4 \mu \mathrm{g} / \mu \mathrm{l}$ for fructose $(0,4 \%), 1 \mu \mathrm{g} / \mu \mathrm{l}$ for raffinose or melibiose $(0,1 \%)$, and traces of an unknown with low $R_{P}$.

I

IL

\author{
Oxylose
}

$\underset{\text { fructose }}{\text { arabinose }} \mathrm{O}_{0}$ mannose

O glucose

galactose $O$

O sucrose

O moltose

lactose 0

Omelexitose
Dructose

A

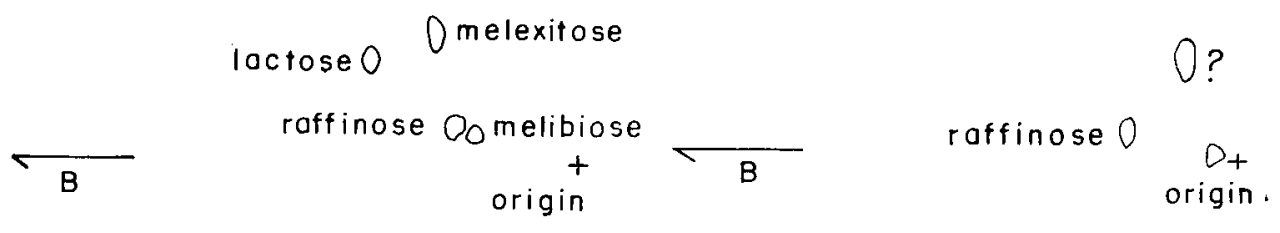

FIG. 1. - Thin-layer chromalograms developed twice in direction A with n-butanol-acetone-water $(4: 5: 1)$ and then twice in direction $\mathrm{B}$ with phenol-water $(3: 1)$. Sugars were stained with Saini's p-aminobenzoic acid reagent. I is $4, \mathrm{~g}$ of standards; II is $1.5 \mu \mathrm{l}$ of stigmatal exudate.

\section{DISCUSSION}

Concentrations of sugar below $5 \%$ do not attract bees to syrups. However, bright sunshine would quickly evaporate water to concentrate the exudate and form a gradient between the plant sap and the evaporating edge of exudate. Bees could select higher or lower concentrations than we did with pipettes. We looked for dead or dying bees in the few tulips found in Tucson and found none. 


\section{RÉSUMÉ}

\section{le galactose, sucre toxique pour les abeilles, EXISTE DANS L'EXSUDAT DES FLEURS DE TULIPE}

La chromatographie en couche mince sur acide silicique a révélé la présence de galactose, d'un peu de fructose et de traces de raffinose (ou mélibiose) dans l'exsudat des stigmates de la tulipe. (Tulipa greigii Regel). Le galactose, de même que le mannose, est toxique pour les abeilles. On n'a pourtant pas trouvé d'abeilles mortes ni mourantes dans les quelques fleurs de tulipe que l'on rencontre à Tucson.

\section{ZUSAMMENFASSUNG}

\section{GALAKTOSE, EIN FÜR DIE HONIGBIENE GIFTIGER ZUCKER IN DEN TULPENBLÜTEN}

Im Nektar von Tulpenblüten (Tulipa greigii Regel) wurden mittels Dünnschichtchromatographie auf Kieselsäure Galaktose, kleine Mengen von Fruktose und Spuren von Raffinose (oder Melibiose) nachgewiesen. Galaktose ist ebenso wie Mannose giftig für Bienen. Dennoch konnten in den wenigen, in Tucson vorkommenden Tulpen keine toten oder sterbenden Bienen gefunden werden.

\section{RÉFÉRENCES}

BARKer R. J. and LehNer Y., 1974. Influence of diet on sugars found by thin-layer chromatography in thoraces of honey bees, Apis mellifera L. J. Exp. Zool. 188 : 157-64.

Geissler G. and Steche W. 1962. Natürliche Trachten als Ursache für Vergiftungserscheinungen bei Bienen und Hummeln. Z. Bienenforsch. 6 : 77.92. 